\title{
Land use/Land Cover Mapping through Remote Sensing and GIS Techniques
}

\section{Priyanka}

\author{
Research Scholar, Department. of Geography, MDU, Rohtak
}

\begin{abstract}
Mapping of land use/land cover is important for global monitoring studies, resource management and planning activities. Human activities have modified environment for thousands of years. Significantly population increase, migration and accelerated socio-economic activities have intensified these environmental changes over the last several centuries. An attempt has been made to study the land uselland cover of Ambala district having a total geographic area of $1574 \mathrm{sq} . \mathrm{km}$. The base map of the study area was prepared using Survey of India Toposheets. The base map was used to prepare thematic map on it. The main objectives of the study were to analyze and interpret satellite data for Land Use/Land Cover mapping and to generate geodatabase of the district in GIS format. Land use/ Land cover categories identified in this area were Agricultural crop land, Plantation, Wastelands, Built-up area \& water body.
\end{abstract}

\section{INTRODUCTION}

Ambala district of Haryana lies between $30^{\circ} 10$ : $31^{\circ} 35^{\prime}$ north latitude and $76^{\circ} 30^{\prime}$ : $77^{\circ} 10^{\prime}$ east longitude. Total geographical area of the district is 1574 sq. km (Fig 3.1). Administratively this district is controlled by Ambala division. It is devide into three tehsils namely Ambala, Barara, and Naraingarh, and sub devided into six development blocks namely Ambala 1,

Ambala 2, Barara, Shahzadpur, Naraingarh,. It is bounded by the district Yamuna Nagar in south-east. To its southern lies Kurukshetra district, while in its west are situated Patiala and Roper districts of Punjab and the union territory of Chandigarh. The Shivalik Range of Solan and Sirmaur districts of Himachal Pradesh bounded the Ambala district in the north and north east. The average altitude from the sea level is 900 feet approximately. Ambala district is comprised in $1574 \mathrm{sq}$. km. It comprises of three tehsils covering the area as mentioned below in table 3.1. As per 2011 Census Ambala tehsil cover 46.63 percentage, Barara 19.31 percentage, and Nraingarh 28.56 percentage.

Objectives: The main objectives of the study are to analyze and interpret satellite data for Land Use/Land Cover mapping and to prepare and compose Land Use/Land Cover maps in GIS environment.

\section{DAta bASE AND ReSEARCh Methodology}

The present study has been carried out utilizing both primary as well as secondary data sets. Primary data includes Survey of India toposheets on 1:50000 scale. For the study, satellite images of Ambala district were acquired for the time period; IRS-P6 LISS-III, for the year 2011 was obtained from (BHUVAN).

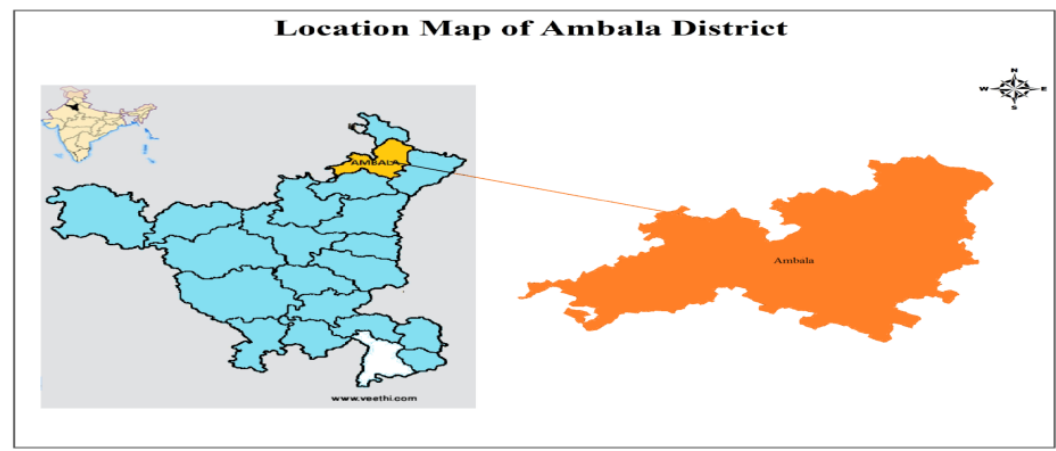

Fig1. 
The administrative state boundary map was also brought to Universal Transverse Mercator project in zone 43 and later the satellite imageries were clipped with the administrative boundary of Ambala. The different False Colour Composite (FCC) of Ambala for different periods were prepared. Secondary data collected from government and semi-government departments, and from published and unpublished reports. The number and arrangement of the toposheets is given in the table 1 and the general characteristics of the satellite image that has been used for the generation of land use map of 2011 are highlighted in the table 2.

Table1. No of toposheets (Number)

\begin{tabular}{|l|l|l|l|}
\hline $53 \mathrm{~B} / 11$ & $53 \mathrm{~B} / 16$ & $53 \mathrm{~F} / 2$ & $53 / 12$ \\
\hline
\end{tabular}

\subsection{Characteristics of Remote Sensing Data Acquired for the Study}

Table2. IRS-P6 LISS III Satellite Image 2011.

\begin{tabular}{|c|c|c|c|c|c|c|c|}
\hline Satellite & Sensor & Band & Orbit & Altitude & Swath & Spectral & Spatial \\
\hline IRS & LISS III & 4 & 24 Days & $\begin{array}{l}140 \\
\mathrm{~km}\end{array}$ & $\begin{array}{l}141 \\
\mathrm{~km}\end{array}$ & $\begin{array}{l}\text { Sensitivity } \\
\mu \mathrm{m}\end{array}$ & Resolution $\mathrm{m}$ \\
\hline Indian & Linear & & & & & $\begin{array}{l}\text { Green- } \\
0.52-0.57\end{array}$ & 23 \\
\hline Remote & Imaging & & & & & $\begin{array}{l}\text { Red- } \\
0.62-0.68\end{array}$ & 23 \\
\hline Sensing & Self & & & & & $\begin{array}{l}\text { Near IR- } \\
0.77-0.86\end{array}$ & 23 \\
\hline & Sensor & & & & & $\begin{array}{l}\text { SWIR- } \\
1.55-1.70\end{array}$ & 23 \\
\hline
\end{tabular}

\section{RESUlts \& DiscusSiON}

\subsection{Land Use of Ambala District 2011}

The land use map of 2011 has been generated from the satellite data and is presented in the table. The table reveals that agriculture is the dominant land use with a total area of 5702.24 ha which constitutes 83.90 percent of the study area followed by build up land categorised urban and rural. Urban land covers the area 5702.24 ha which is 3.62 percent of the total area. Rural settlement occupies 3005.10 ha which is 1.91 percent of the study area. Fallow land another major land use category spread over an area 5259.30 ha occupying 3.34 percent of the study area.

Table3. Land Use of Ambala District 2011

\begin{tabular}{|l|c|r|}
\hline Land use/Land Cover Class & Area in ha & Area in percentage \\
\hline Rural & 3005.10 & 1.91 \\
\hline Urban & 5702.24 & 3.62 \\
\hline Agriculture & 132056.38 & 83.90 \\
\hline Fallow Land & 5259.30 & 3.34 \\
\hline Forest Plantation & 1572.49 & 1.00 \\
\hline Scrub land & 1230.62 & 0.78 \\
\hline Waterlogged Area & 2056.21 & 1.31 \\
\hline River & 3467.59 & 2.20 \\
\hline Pond,Lakes & 3050.07 & 1.94 \\
\hline Total & 157400.00 & 100.00 \\
\hline
\end{tabular}

Source: Derived from IR-P6 LISS III Satellite Image, 2011.

Forest plantation is next land use category over an area 1572.49 ha which constitutes 1.00 percent of the total area. Waste land is another major land use class in the study area divided into scrub land and waterlogged area. Scrub land least coverage area in Ambala district. Total area under this category is 1230.62 ha which is only 0.78 percent of the study area. 


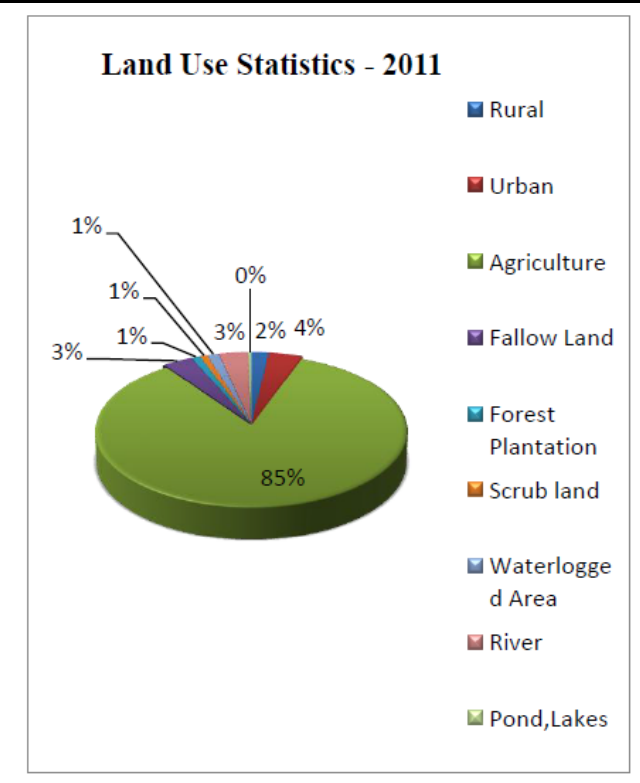

Fig2.

Source: Computed from IRS-P6 LISSIII Satellite Image, 2011.

Waterlogged occupying an area 2056.21 ha which is 1.31 percent of the total area. Water bodies' category includes pond, lakes and river. A total area of 3467.59 ha occupied by rivers which is 2.20 percent of the total area. Lakes and pond cover an area 3075 ha which is 1.94 percent of the study area.

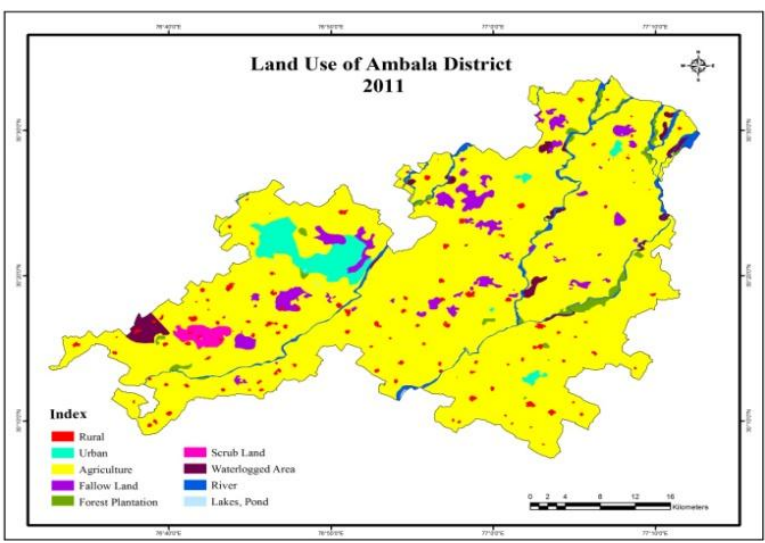

Fig3.

Source: Generated from IRS-P6 LISSIII Satellite Image, 2011.

\section{Coclusion}

Land use has drastically changed in the Ambala district since 2001.

$>$ Scrub land, wetlands and river have suffered the most.

\section{REFERENCES}

[1] Arvind C. Pandy and M. S. Nathawat, (2006) 'Land Use Land Cover Mapping Through Digital Image Processing of Satellite Data - A case study from Panchkula, Ambala and Yamunanagar Districts, Haryana State, India'

[2] Bhardwaj, P., and Kumar, S., (2012) 'Urban Expention and Land Use Change Analysis of Karnal City in Haryana: A Study Based on Open Source Satellite Data'. International Journal of Emerging Technology and Advanced Engineering, 2(12):182-186.

[3] Foley, J.A., et al., (2005) 'Global Consiquencies of Land Use'. www.sciencemag.ogr. 309, 570574.

[4] Jaiswal, R.K., Saxena, R., and Mukherjee, S., (1999) 'Application of Remote Sensing Technology for Landuse/Landcover change analysis'. J. Indian Soc. Remote Sensing, 27(2):123128 
[5] Kimiteru, S., and Monirul islam, M D.,(2000)' Flood hazard map and land development priority map developed using NOAA AVHRR and GIS data'. Proceedings of ACRS 2000.

[6] Kumar. M., (2014) 'High Resolution Satellite Data for Land use/Land cover Mapping in Rohtak District Haryana, India'. Redix International Journal of Resaerch in Social Science, 3(1)1-14.

[7] Resourcesat-1 (IRS-P6) Data User's Handbook, National Remote Sensing Agency, Department of Space, Goveronment of India.

[8] Saini, S.S., and Kaushik, S.P., (2011) 'Land Use Changes in Haryana Sub Region of Chandigarh Periphery Controlled Area - A Spatio - Temporal Study'. Institute of Town Planners, India Journal, 8(4):96-106.

[9] Sandhu, HAS., et. al., (2013) 'Temporal Analysis of Chandigarh and Surroundings Areas Using RS/GIS Techniques'. International Journal of Computer Science and Communication Engineering, ISSN 3319-7080. 121-125. 